\title{
PROBLEMATIKA PENGGUNAAN RAGAM BAHASA JURNALISTIK PADA MEDIA MASSA DAN IMPLIKASINYA TERHADAP PEMBINAAN BAHASA INDONESIA DI MASYARAKAT
}

\author{
N Lia Marliana dan Edi Puryanto \\ Jurusan Pendidikan Bahasa dan Sastra Indonesia \\ FBS Universitas Negeri Jakarta \\ Email: edy_pur@yahoo.com
}

\begin{abstract}
Good print media are those prioritizing the writing quality. Although they emphasize more on effectiveness, efficiency, and cost, they should take into account of the writing quality, without violating the Indonesian language rules. Some violations found in journalistic writing include: (1) spelling and punctuation violations, (2) grammatical violations, consisting of errors in syllable separation, morphological violations, and syntactic errors, (3) semantic violations, and (4) discourse violations. Other problems concern loanwords, namely foreign words that are already popular in the community. The replacement of foreign words absorbed into the Indonesian language with unavailable Indonesian equivalents results in difficulty.
\end{abstract}

Keywords: journalistic language, mass media, language maintenance

\section{A. PENDAHULUAN}

Bahasa yang digunakan dalam media cetak adalah bahasa jurnalistik. Bahasa jurnalistik biasanya memperhatikan beberapa kaidah bahasa Indonesia yang baik dan benar. Namun, masih ada media cetak yang mengabaikan kaidah bahasa Indonesia yang baik dan benar. Padahal, media cetak berkepentingan untuk membina dan mengembangkan bahasa Indonesia yang baik dan benar kepada masyarakat. Walaupun dalam bahasa jurnalistik, khususnya surat kabar, lebih mementingkan efektivitas, efisiensi, dan biaya, tetapi mutu tulisan dalam surat kabar tetaplah harus diperhatikan, tanpa harus menyimpang dari kaidah bahasa Indonesia yang telah ditetapkan.

Penyimpangan kaidah dalam bahasa jurnalistik kerap kali menimbulkan polemik dalam masyarakat. Media cetak tidak menggunakan bahasa standar (bahasa baku). Misalnya, media cetak yang satu menggunakan kata 'pemboman', sedangkan yang lain menggunakan kata 'pengeboman', serta perbedaan ejaan "telepon" dan "telefon". Penyimpangan-penyimpangan dan ketidakseragaman ini, yang paling bertanggung jawab adalah redaktur bahasa di surat kabar tersebut karena salah satu fungsi redaktur bahasa adalah membenahi tulisan para wartawan atau penulis agar lebih komunikatif dan mudah dicerna oleh pembaca (Hidayat, 2002:2).

Surat kabar boleh-boleh saja tidak seragam, tetapi ketidakseragaman ini tetap tidak boleh menyimpang dari kaidah bahasa Indonesia yang telah ditetapkan oleh Pusat Bahasa, apalagi jika tulisan yang diterbitkan surat kabar tersebut berdampak terhadap mutu tulisan. Walaupun salah satu sifat bahasa adalah arbitrer, bukan berarti para redaktur bahasa di setiap surat kabar dapat menuliskan kata, istilah, afiksasi apa pun yang mereka inginkan, dengan hanya memperhatikan keinginan dan kebiasaan pemakaian bahasa itu dalam masyarakat, sehingga mengabaikan mutu 
tulisan berdasarkan kaidah bahasa Indonesia yang baik dan benar.

Terkait dengan hal di atas, ada tuduhan bahwa pers/wartawan adalah salah satu faktor pendukung yang 'merusak' bahasa Indonesia. Meskipun pers berperan mencatat apa yang terjadi atau apa yang diucapkan oleh pejabat, misalnya, bahasa yang 'kacau' dalam pemberitaan pers mencerminkan bahasa dari pihak yang diberitakan ataukah pihak yang menulis berita. Redaktur bahasa tentu akan menghadapi dilema, harus membiarkan begitu saja ucapan yang 'kacau' atau harus memperbaiki bahasanya. Hal ini tentu dapat berimplikasi pada penilaian negatif masyarakat terhadap pemimpinnya dan ini juga berimplikasi bahwa pernyataan pejabat itu tidak sesuai lagi karena telah dikemas sedemikian rupa sehingga 'kebodohan' seorang pejabat tidak diketahui oleh masyarakatnya. George Orwell pernah mengatakan dalam artikel yang bertajuk "Tentang Bahasa di Media Massa", "Jika pikiran mengkorupsikan bahasa, bahasa dapat pula mengkorupsikan pikiran."(Hidayat, 2002: 2). Ini berarti, apa yang diucapkan oleh narasumber janganlah dituliskan berbeda dengan yang terucap. Di sinilah peran redaktur bahasa sangat dibutuhkan dalam mengolah tulisan tersebut dengan menggunakan bahasa Indonesia yang baik dan benar sebagai medianya.

Dengan demikian, kalau ada tuduhan bahwa tulisan-tulisan dalam surat kabar sering 'merusak' bahasa, 'kerusakan' itu bukan disebabkan oleh target pasar, kemampuan berbahasa SDM, atau arogansi kalangan pers (Tendy, 2002), melainkan karena redaktur bahasa yang tidak berperan sebagaimana mestinya. Alih-alih hendak menjadikan media massa sebagai sarana pendidikan bahasa yang baik dan benar, malah menjadikan tulisantulisan yang disunting oleh redaktur bahasa sebagai suatu penyimpangan. Para redaktur pun menyibukkan diri dalam hal-hal sepele yang dianggap besar 'berbekal keyakinan mulia sebagai polisi bahasa'. Padahal, sebenarnya mereka "terjebak" menjadi semacam korektor untuk memperbaiki ejaan kata-kata seperti 'sekitar' menjadi 'sekira', 'mempunyai' menjadi 'memunyai', 'pengeboman' menjadi 'pemboman', 'telepon' menjadi 'telefon', atau 'olahraga' menjadi 'olah raga', dan tanpa sadar telah mengindahkan kaidah berbahasa Indonesia.

Penggunaan bahasa jurnalistik dalam surat kabar berkaitan dengan kaidah dalam bahasa jurnalistik yang telah ditetapkan yang dijadikan pedoman para redaktur bahasa dalam meningkatkan mutu tulisan yang diterbitkan dalam surat kabar.

\section{B. RAGAM BAHASA JURNALISTIK DAN PERMASALAHANNYA}

\section{Bahasa Jurnalistik}

Ragam Bahasa adalah variasi bahasa menurut pemakaian, yang berbeda-beda menurut topik yang dibicarakan, menurut hubungan pembicara, kawan bicara, orang yang dibicarakan, serta menurut medium pembicara (Bachman, 1990). Ragam bahasa yang oleh penuturnya dianggap sebagai ragam yang baik (mempunyai prestise tinggi), yang biasa digunakan di kalangan terdidik, di dalam karya ilmiah (karangan teknis, perundang-undangan), di dalam suasana resmi, atau di dalam surat menyurat resmi (seperti surat dinas) disebut ragam bahasa baku atau ragam bahasa resmi.

Bahasa jurnalistik atau biasa disebut dengan bahasa pers, merupakan salah satu ragam bahasa kreatif bahasa Indonesia di samping terdapat juga ragam bahasa akademik (ilmiah), ragam bahasa usaha (bisnis), ragam bahasa filosofik, dan ragam bahasa literer (sastra) (Suroso, 2001:1). Ragam bahasa jurnalistik memiliki kaidah-kaidah tersendiri yang membedakannya dengan ragam bahasa yang lain. Bahasa jurnalistik merupakan bahasa yang digunakan oleh wartawan (jurnalis) dalam menulis karya-karya jurnalistik di media massa (Anwar, 1991).

Bahasa jurnalistik itu sendiri juga memiliki karakter yang berbeda-beda berdasarkan jenis tulisan apa yang akan diberitakan. Bahasa jurnalistik yang digunakan untuk menulis berita utama -ada yang menyebut 
laporan utama, forum utama- akan berbeda dengan bahasa jurnalistik yang digunakan untuk menulis tajuk dan features. Karakteristik bahasa jurnalistik dipengaruhi banyak hal yang terkait dengan penentuan masalah, jenis tulisan, pembagian tulisan, dan sumber (bahan tulisan). Namun demikian, bahasa jurnalistik tidak boleh meninggalkan kaidah yang dimiliki oleh ragam bahasa Indonesia baku dalam hal pemakaian kosakata, struktur sintaksis, dan wacana. Perlu disadari bahwa bahasa jurnalistik memiliki sifat yang khas yaitu singkat, padat, sederhana, jelas, lugas, dan menarik. Kosakata yang digunakan dalam bahasa jurnalistik mengikuti perkembangan bahasa dalam masyarakat.

Ragam jurnalistik memiliki sifat yang khas disebut gaya selingkung. Gaya selingkung ini merupakan gaya bahasa yang ditentukan redaksi sebagai salah ciri khas. Selain itu, gaya selingkung ini bisa dibilang merupakan gaya bahasa baku bagi redaksi terkait. Sayangnya, gaya selingkung tersebut sering kali bertentangan dengan ejaan baku yang berlaku. Pada tataran morfologi, pelanggaran kaidah morfologi sebagai perwujudan gaya selingkung penerbit juga dimunculkan. Sebagai contoh, kata mempercayai bagi sejumlah penerbit merupakan bentuk yang baku, sedangkan penerbit lain menggunakan kata memercayai. Padahal proses pembentukannya sama saja seperti pada kata memukul, yaitu memperoleh akhiran $-i$ untuk kemudian mendapat awalan $m e N-$. Kata-kata yang lain bisa disebutkan antara lain mengkomunikasikan, mempertahankan, dan sebagainya.

Dalam tataran tanda baca pun hal serupa juga terjadi. Adapun tanda baca yang paling sering disalahgunakan ialah tanda petik tunggal yang sering kali menggantikan peran tanda petik ganda.Tampaknya kebanyakan mereka beranggapan bahwa tanda petik ganda hanya digunakan untuk kalimat langsung. Padahal tanda petik ganda berfungsi lain, di antaranya untuk mengapit istilah yang masih kurang dikenal atau kata yang memiliki arti khusus. Sebaliknya dengan tanda petik tunggal yang hanya memiliki dua fungsi, yaitu mengapit petikan yang terdapat di dalam petikan lain, dan mengapit terjemahan atau penjelasan kata atau ungkapan asing.

Penyimpangan kaidah dalam bahasa jurnalistik sepertinya menjadi hal yang lazim sehingga dianggap pembakuan bahasa dapat dilakukan dan ditentukan oleh media massa, mestinya tetap harus mengacu pada kaidah bahasa yang telah baku.. Perlu ditekankan di sini, media massa (surat kabar) sebenarnya memiliki nilai pembinaan yang jauh lebih dekat dengan masyarakat.

Wahyono (1995) menemukan kemubaziran bahasa wartawan di Semarang dan Yogyakarta pada aspek gramatikal (tatabahasa), leksikal (pemilihan kosakata) dan ortografis (ejaan). Berdasarkan aspek kebahasaan, kesalahan tertinggi yang dilakukan wartawan terdapat pada aspek gramatikal dan kesalahan terendah pada aspek ortografi. Berdasarkan jenis berita, berita olahraga memiliki frekuensi kesalahan tertinggi dan frekuensi kesalahan terendah pada berita kriminal. Penyebab wartawan melakukan kesalahan bahasa dari faktor penulis karena minimnya penguasaan kosakata, pengetahuan kebahasaan yang terbatas, dan kurang bertanggung jawab terhadap pemakaian bahasa karena kebiasaan lupa dan pendidikan yang belum baik. Faktor di luar penulis yang menyebabkan wartawan melakukan kesalahan dalam menggunakan bahasa Indonesia adalah karena keterbatasan waktu menulis, lama kerja, banyaknya naskah yang dikoreksi, dan tidak tersedianya redaktur bahasa dalam surat kabar.

\section{Penyimpangan Bahasa Jurnalistik}

Terdapat beberapa penyimpangan bahasa jurnalistik dibandingkan dengan kaidah bahasa Indonesia baku. Penyimpangan itu antara lain sebagai berikut.

1) Penyimpangan Klerikal (Ejaan dan Tanda Baca)

Kesalahan ini hampir setiap kali dijumpai dalam surat kabar. Kesalahan ejaan juga terjadi dalam penulisan kata, seperti: Jumat ditulis Jum'at, khawatir ditulis kuatir, jadwal ditulis jadual, sinkron ditulis singkron, 
dan kesalahan tanda baca dapat dijumpai dalam penggunaan tanda titik, tanda koma, tanda hubung dan lain-lain.

2) Penyimpangan gramatikal yang terdiri atas hal-hal sebagai berikut.

a. Kesalahan pemenggalan

Terkesan setiap ganti garis pada setiap kolom kelihatan asal penggal saja. Kesalahan ini disebabkan pemenggalan bahasa Indonesia masih menggunakan program komputer berbahasa Inggris. Hal ini sudah bisa diantisipasi dengan program pemenggalan bahasa Indonesia.

b. Penyimpangan morfologis

Penyimpangan ini sering dijumpai pemakaian kata kerja tidak baku dengan penghilangan afiks. Afiks pada kata kerja yang berupa prefiks atau awalan dihilangkan. Begitu juga pada penggunaan frase atau kelompok kata. Sering ditemukan judul berita misalnya, Polisi Tembak Mati Lima Perampok Nasabah Bank. Israel Tembak Pesawat Mata-mata.

c. Kesalahan sintaksis

Kesalahan berupa pemakaian tatabahasa atau struktur kalimat yang kurang benar sehingga sering mengacaukan pengertian. Hal ini disebabkan logika yang kurang bagus. Contoh: Kerajinan Kasongan Banyak Diekspor Hasilnya Ke Amerika Serikat. Seharusnya judul tersebut diubah Hasil Kerajinan Desa Kasongan Banyak Diekspor Ke Amerika. Kasus serupa sering dijumpai baik di koran lokal maupun koran nasional.

3) Penyimpangan semantik

Kesalahan ini sering dilakukan dengan alasan kesopanan (eufemisme) atau meminimalkan dampak buruk pemberitaan. Bahkan bahasa jurnalistik mengangkat diksi yang berbau sarkasme atau dapat mengandung unsur kekerasan, paling tidak dapat menimbulkan suatu pertikaian antar kedua belah pihak karena bahasa yang digunakan sangat menyinggung pribadi tertentu. Pada era kebebasan pers seperti sekarang ini, kecenderungan pemakaian kosakata yang bias makna semakin banyak. Kosakata dari surat kabar yang mengalami penyimpangan makna (semantik) dengan alasan kesopanan antara lain;

Penyesuaian tarif BBM merupakan kebijakan pemerintah yang tidak populis. Pemakaian kata penyesuaian tarif tidak dapat dimaknai dari makna lugas saja tetapi harus dilihat dari makna figuratif (kias) yang mengandung eufimisme dengan alasan untuk kesopanan.

- Banyak mahasiswa ditangkap karena mengganggu kestabilan pemerintah dikatakan "diamankan".

- Pemerintah mendapat utang dari pihak luar negeri dikatak mendapat "kucuran dana" atau "uang pinjaman".

- Sekelompok masyarakat terkena bususng lapar dikataka kurang gizi.

- Seseorang melakukan kejahatan dan kemudian dilaporkan ke polisi cukup dengan kata "dipolisikan".

Kosakata yang mengandung kekerasan dalam rubrik olah raga, misal kata memukul, menghantam, menggasak, melibas, menghancurkan, menggulung, menekuk, mencukur, menghantam, menggunduli, memepermalukan, menelanjangi dan sebagainya. Semua kata itu digunakan sebagai sinonim dari kata "mengalahkan". Namun bila dilihat makna yang tersirat bukan hanya sekedar makna "mengalahkan" tetapi mengambil perbandingan dengan tindakan lain yang mungkin menyiratkan kekerasan. Beberapa kata tersebut tidak dimaksudkan untuk menyakiti hati orang lain, mungkin hanya gaya bahasa semata, tetapi dapat menyebabkan orang lain merasa tersakiti.

4) Penyimpangan dari aspek kewacanaan.

Untuk mengetahui adanya penyimpangan bahasa jurnalistik dari aspek kewacanaan dari penggunaan bahasa yang dilihat dari makna bahasa yang berkaitan dengan aktivitas dan sistem - sistem di luar bahasa. Bahasa jurnalistik merupakan teks wacana dari bentuk pemakaian bahasa yang diatur oleh sistem sosial budaya. Analisis fungsional menekankan pada makna sosial dan makna budaya bukan pada makna semantik. 
Menurut Grice (Schiffrin, 1994) makna sosial dan makna budaya ini disebut makna tidak alamiah (non-natural meaning) atau maksud penutur.

Pemakaian bahasa dalam jurnalistik dengan makna yang terselubung berarti memberikan informasi yang tidak akurat, tidak disampaikan secara terbuka tetapi dibungkus oleh tuturan yang diperhalus, diwajarkan, atau dipositifkan. Tidak semua pers mampu mengemban peran dan fungsinya dengan baik. Masih ada pers yang tidak independen dan berkepentingan secara komersil, sehingga terkadang menyajikan berita yang tidak sesuai dengan fakta dengan maksud untuk membentuk opini publik dan sebagai industri informasi yang komersil. Apabila pers menulis berita yang tidak realistis berarti pers telah melakukan kesalahan dengan membuat kebohongan publik. Sering kali yang ditulis dan disampaikan media massa itu hanya sekadar pendapat, pandangan, praduga bukan fakta, Akan tetapi, disampaikan berulang-ulang dan dikemas dalam bahasa berita yang tanpa disadari oleh masyarakat menjadi suatu kebenaran. Pemberitaan yang begitu santer dengan pandangan dan pendapat yang berbeda dari masing- masing media menjadikan isi berita tidak lagi relistis, bahkan terlalu dibesarbesarkan yang justru membuat bingung para pembacanya.

Permasalahan lain yang muncul adalah masalah peminjaman istilah - istilah asing atau perkataan-perkataan asing yang pada dasarnya sudah populer di masyarakat. Penggunaan istilah asing dalam penulisan berita bertaburan di media massa. Tetapi, Penggantian istilah asing yang sudah diserap ke dalam bahasa Indonesia dengan istilah yang tidak ada penggantinya dalam bahasa Indonesia, akan menimbulkan kesulitan.

Menurut sejarah perkembangannya, daftar kosakata bahasa Indonesia diperkaya dengan tiga cara: (1) melalui peminjaman dari bahasa asing (banyak meminjam dari bahasa Portugis, Belanda, Inggris, Cina, dan Arab); (2) melalui peminjaman dari bahasa dialek (di antaranya bahasa dialek Betawi banyak mempengaruhi bahasa Indonesia); (3) melalui peminjaman dari bahasa pergaulan.

Dalam usaha memperkaya bahasa melaluil peminjaman dari bahasa dialek dan bahasa pergaulan ini, pers juga berjasa mempopulerkan kata-kata pinjaman dari golongan-golongan atilt lingkunganlingkungan sosial di desa, di kota, di ladang, di pabrik, di pasar dan sebagainya, yang akhirnya menjadi kosakata-kosakata dalam bahasa nasional. Oleh karena itulah, media massa yang tidak mau ketinggalan ingin memberikan kontribusi kepada perkembangan bahasa nasionalnya, sebaiknya berusaha mengetahui bahasa yang digunakan oleh kelompok masyarakat yang diliputnya, sehingga istilahistilah yang dipakai oleh llingkungan kelompok masyarakat tersebut dapat dipopulerkan untuk memperkaya bahasa nasional.

\section{Kendala Berbahasa yang Baik dalam Jurnalistik}

Pertanggungjawaban media massa tentang bahasa yang ditulisnya begitu berat karena merupan sarana penyebaran dan pembinaan bahasa Namun ada beberapa kendala yang menghalangi terciptanya penggunaan bahasa jurnalistik yang baik dalam jurnalistik. Ada desakan desakan, tekanantekanan atau kekecewaan-kekecewaan yang membuat bahasa jurnalistik menjadi bahasa surat kabar. Ada jebakan-jebakan yang menjerat para wartawan yang mengetahui bagaimana berbahasa dengan baik tetapi ternyata terpeleset ke jurang kesalahan. Ada lima kendala utama: (1) menulis di bawah tekanan waktu; (2) kemasabodohan \& kecerobohan; (3) tidak mau mengikuti petunjuk; (4) mencontoh bahasa publik figur; (5) kesalahan pemilihan diksi.

\section{1) Menulis di Bawah Tekanan Waktu \\ Kecepatan penyampaian berita merupakan salah satu keharusan dalam menulis berita. Baik kecepatan itu dalam hal cara menyampaikan informasi, maupun kecepatan dalam arti penulisannya karena dikejar waktu oleh tenggat (deadline) yang harus dipatuhi.}


Penulis berita yang dikejar tenggat nyaris tidak punya waktu untuk memoles tulisannya, untuk memperindah tulisannya dengan pilihan katakata yang tepat, untuk memangkas kalimatkalimat yang tidak perlu agar membuat tulisan buruk menjadi baik atau membuat tulisan baik menjadi sempurna. Sifat penanganan berita yang tergesa-gesa itu sedikit banyak menjadi kendala untuk tercapainya kualitas penulisan berita yang baik.

\section{2) Kemasabodohan dan Kecerobohan}

Selain ketergesa-gesaan, hal lain yang dapat mengencerkan gaya penulisan berita adalah kemalasan. Kemalasan yang dimaksudkan di sini adalah kemalasan berpikir, kemalasan mencari kata-kata atau istilah-istilah yang tepat. Orang cenderung mengikuti apa yang sudah dilakukan orang lain tidak mau menciptakan sendiri. Dengan adanya kemalasan ini timbul sikap masa bodoh,.Dari sikap masabodoh yang diakibatkan oleh sikap tidak bertanggungjawab timbul kecerobohan. Wartawan ceroboh menggunakan istilah-istilah yang sudah klise, tidak ada penyegaran dalam menggunakan diksi, dan redaktur juga demikian. Akibatnya, ada sebuah surat kabar lokal yang menuliskan judul seperti ini: "Bordir Tasik Terkenal, Tapi tak Punya Khas." Redaktur yang membuat judul ini, yang mungkin hanya mengangkatnya dari dalam berita yang ditulis wartawannya sudah dihinggapi sikap malas tadi. Maksud judul itu barangkali: "Bordir Tasik Terkenal, Tapi Tak Punya Ciri Khas."

Kemasabodohan dan kecerobohan ini juga muncul ketika penulis berita malas mencari kata-kata yang tepat untuk sesuatu maksud yang hendak ia katakan. Padahal, ini merupakan tonggak untuk dapat menulis baik. Bahasa Indonesia jika digunakan dengan baik dan benar akan menjadi alat efektif untuk menyampaikan informasi maupun penerangan. Bahasa ini meskipun sering dikeluhkan orang kata-katanya bersuku banyak, tetapi jika digunakan dengan apik dan tidak ceroboh akan menghasilkan kalimat-kalimat yang memenuhi syarat hemat kata, sederhana, jelas, dan langsung.

\section{3) Malas Mengikuti Petunjuk}

Petunjuk dalam menggunakan bahasa tertulis adalah tatabahasa, kamus, dan pedoman Ejaan Yang disempurnakan (EYD). Petunjuk bahasa untuk jurnalistik bisa ditambah lagi, yaitu "Sepuluh Pedoman Pemakaian Bahasa dalam Pers"). Contoh konstruksi kalimat rancu seperti ini: "Dengan didirikannya koperasi di desa itu, akan memberikan kesejahteraan kepada warga."

Kalimat di atas adalah kalimat majemuk dengan anak kalimat preposisional (memakai kata sambung: dengan). Jika diuraikan, kalimat tersebut terdiri dari dua frasa, yaitu frasa "dengan didirikannya koperasi" dan frasa "akan memberikan kesejahteraan" Padahal, sebagai kalimat majemuk kalimat tersebut seharusnya terdiri dari anak kalimat dan induk kalimat yang konstruksi kalimatnya sempurna, yaitu ada pokok kalimat (subjek)-nya, ada sebutan (predikat)-nya, dan kalau perlu ada pelengkap penderita (objek)-nya. Kalimat majemuk tersebut tidak sempurna karena kita tidak menemukan mana induk kalimatnya. Jika frasa "akan memberikan kesejahteraan" dijadikan induk kalimat, maka seharusnya ia mempunyai "subjek" atau "pokok kalimat" agar ia menjadi kalimat sempurna, misalnya menjadi: "kesejahteraan pun akan dapat diberikan kepada warga." Kalimat ini memiliki subjek, yaitu "kesejahteraan" sebagai subjek dan "diberikan" sebagai predikat. Jadi, kalimat majemuk di atas sekarang memenuhi ketentuan tatabahasa dan karenanya lebih enak dipahami: "Dengan didirikannya koperasi di desa itu, kesejahteraan pun akan dapat diberikan kepada warga."

\section{4) Mencontoh Bahasa Publik Figur}

Tokoh terkenal biasanya menjadi acuan khalayak, dan tidak mustahil ditiru orang banyak. Ini bukan saja terjadi dalam perilaku, dalam cara berpakaian, tetapi juga dalam berbahasa. Dulu, pada masa pemerintahan Presiden Soekarno, banyak para petinggi negara mengucapkan akhiran kata kan menjadi ken karena Bung Karno berbuat demikian. 
Misalnya kata 'akan' menjadi 'aken', kata 'memberikan' menjadi 'memberiken'. Presiden Soeharto yang semasa pemerintahan Soekarno masih menjadi perwira tinggi, bahkan sampai beliau menjadi presiden pun masih belum dapat meninggalkan kebiasaan mengucapkan 'ken' itu.

Dalam Jurnalistik, penggunaan katakata "pasalnya" dan "akan halnya" menjadi mode dalam menulis berita karena dari kata itu dimulai penggunaannya secara menarik oleh majalah Tempo. Ikut-ikutan seperti itu memang tidak dilarang. Tetapi jika penggunaan katakata populer itu dilakukan terlalu sering, maka "pesonanya" akan lenyap. Bahkan, tidak mustahil katakata tersebut akan menjadi klise dan tidak menarik.

\section{5) Kesalahan Pemilihan Diksi}

Pilihan kata (diksi) merupakan hal yang penting dalam menulis, terutama dalam menulis berita untuk suratkabar. ketepatan dalam memilih kata untuk kalimat yang dibuat. Misalnya, "memukul" lain daripada "meninju." Memukul bisa dengan telapak tangan atau dengan alat pemukul, tetapi meninju hanya dengan tinju, dengan kepalan tangan anda. Contoh lainnya:

- Perampok itu menginjak punggung pembantu rumah tangga tersebut ketika perempuan itu jatuh telentang. (Telentang artinya tergeletak dengan wajah ke atas. Jadi, mustahil diinjak punggungnya).

- Hakim menunda sidang selama setengah jam, tetapi ketika kembali ke ruangan sidang, pembela tetap pada pendiriannya. (tidak jelas siapa yang kembali ke ruang sidang - hakim atau pembela).

- Kata yang enak didengar tetapi maknanya sering mengecoh kata mengungkapkan . Misal dalam berita "Polisi mengungkapkan bahwa bulan lalu dalam periode yang sama seperti tahun silam, perampokan menurun dengan 64 kejadian" Mengungkapkan artinya melahirkan perasaan hati dengan perkataan, air muka atau gerak-gerik). Jadi, kata yang tepat bukan "mengungkapkan" tetapi "mengemukakan".
Penggunaan bahasa yang "rusak" pada media massa dipengaruhi oleh faktor eksternal dan internal. Adapun yang dimaksud dengan faktor eksternal adalah perilaku Pusat Bahasa yang dinilai tidak konsisten dalam menjalankan kebijakan berbahasa Indonesia yang baik dan benar, sedangkan yang dimaksud dengan faktor internal muncul dari kalangan media massa itu sendiri. Contoh-contoh mengenai penggunaan bahasa yang "rusak" pada media massa itu diakibatkan oleh (a) target pasar; (b) kemampuan berbahasa sumber daya manusia; hingga (c) arogansi kalangan pers. Oleh karena itu, beberapa media massa yang telah menyadari kekurangan itu mulai mengubah struktur organisasi bagian redaksi mereka dengan menempatkan editor/redaktur bahasa. Editor/redaktur bahasa inilah yang akan menjadi "polisi bahasa" dalam media massa.

Untuk menghindari beberapa kesalahan dan kendalanya seperti diuraikan di atas adalah dengan cara melakukan kegiatan penyuntingan, baik menyangkut pemakaian kalimat, pilihan kata, maupun ejaan. Selain itu, pemakai bahasa jurnalistik yang baik tercermin dari kesanggupannya menulis paragraf yang baik. Syarat untuk menulis paragraf yang baik tentu memerlukan persyaratan menulis kalimat yang baik pula. Paragraf yang berhasil tidak hanya lengkap pengembangannya, tetapi juga menunjukkan kesatuan dalam isinya. Paragraf menjadi rusak karena penyisipan-penyisipan yang tidak bertemali dan pemasukan kalimat topik kedua atau gagasan pokok lain ke dalamnya. Selain itu, kalimat topik dan kalimatkalimat penjelasnya pun semestinya menggunakan bahasa Indonesia baku.

\section{PRINSIP DASAR BAHASA JURNALISTIK}

Menurut Badudu (1996) bahasa jurnalistik memiliki sifat-sifat khas yaitu singkat, padat, sederhana, lugas, menarik, lancar, dan jelas. Sifat-sifat itu harus dimiliki oleh bahasa pers, bahasa jurnalistik, mengingat surat kabar dibaca oleh semua lapisan masyarakat yang tidak sama tingkat pengetahuannya. Oleh karena itu, beberapa ciri 
yang harus dimiliki bahasa jurnalistik antara lain sebagai berikut.

1) Singkat, artinya bahasa jurnalistik harus menghindari penjelasan yang panjang dan bertele-tele.

2) Padat, artinya bahasa jurnalistik yang singkat itu sudah mampu menyampaikan informasi yang lengkap. Semua yang diperlukan pembaca sudah tertampung di dalamnya. Menerapkan prinsip $5 \mathrm{~W}$ dan 1 $\mathrm{H}$, membuang kata-kata mubazir, dan menerapkan ekonomi kata.

3) Sederhana, artinya bahasa pers sedapatdapatnya memilih kalimat tunggal dan sederhana, bukan kalimat majemuk yang panjang, rumit, dan kompleks. Selain itu, sederhana berarti kalimat yang efektif, praktis, sederhana pemakaian kalimatnya, dan tidak berlebihan pengungkapannya (bombastis)

4) Lugas, artinya bahasa jurnalistik mampu menyampaikan pengertian atau makna informasi secara langsung dengan menghindari bahasa yang berbunga-bunga.

5) Menarik, artinya dengan menggunakan pilihan kata yang masih hidup, tumbuh, dan berkembang. Menghindari kata-kata yang sudah mati.

6) Jelas, artinya informasi yang disampaikan jurnalis dengan mudah dapat dipahami oleh khalayak umum (pembaca). Struktur kalimatnya tidak menimbulkan penyimpangan/pengertian makna yang berbeda, menghindari ungkapan bersayap atau bermakna ganda (ambigu). Oleh karena itu, seyogyanya bahasa jurnalistik menggunakan kata-kata yang bermakna denotatif.

Dalam menerapkan ke-6 prinsip tersebut tentunya diperlukan latihan berbahasa tulis yang terus-menerus dan melakukan penyuntingan yang tidak pernah berhenti. Dengan berbagai upaya pelatihan dan penyuntingan, barangkali akan bisa diwujudkan keinginan jurnalis untuk menyajikan ragam bahasa jurnalistik yang memiliki rasa dan memuaskan selera pembacanya, tanpa menyimpang dari kaidah bahasa Indonesia yang telah ditetapkan.

Terdapat empat prinsip retorika tekstual yang dikemukakan Leech, yaitu prinsip prosesibilitas, prinsip kejelasan, prinsip ekonomi, dan prinsip ekspresifitas.

1) Prinsip prosesibilitas, menganjurkan agar teks disajikan sedemikian rupa sehingga mudah bagi pembaca untuk memahami pesan pada waktunya. Dalam proses memahami pesan penulis harus menentukan (a) bagaimana membagi pesan-pesan menjadi satuan; (b) bagaimana tingkat subordinasi dan seberapa pentingnya masing-masing satuan, dan (c) bagaimana mengurutkan satuan-satuan pesan itu. Ketiga macam itu harus saling berkaitan satu sama lain. Penyusunan bahasa jurnalistik dalam surat kabar berbahasa Indonesia, yang menjadi faktafakta harus cepat dipahami oleh pembaca dalam kondisi apa pun agar tidak melanggar prinsip prosesibilitas ini. Bahasa jurnalistik Indonesia disusun dengan struktur sintaksis yang penting mendahului struktur sintaksis yang tidak penting.

2) Prinsip kejelasan, yaitu agar teks itu mudah dipahami. Prinsip ini menganjurkan agar bahasa teks menghindari ketaksaan (ambiguity). Teks yang tidak mengandung ketaksaan akan dengan mudah dan cepat dipahami.

3) Prinsip ekonomi. Prinsip agar teks itu singkat tanpa harus merusak dan mereduksi pesan.

4) Prinsip ekspresivitas. Prinsip ini dapat pula disebut prinsip ikonisitas. Prinsip ini menganjurkan agar teks dikonstruksi selaras dengan aspek-aspek pesan. Dalam wacana jurnalistik, pesan bersifat kausalitas dipaparkan menurut struktur pesannya, yaitu sebab dikemukakan terlebih dahulu baru dikemukakan akibatnya. Demikian pula bila ada peristiwa yang terjadi berturut-turut, maka peristiwa yang terjadi lebih dulu akan dipaparkan lebih dulu dan peristiwa yang terjadi kemudian dipaparkan kemudian. 


\section{PEMBINAAN DAN PENGEMBANGAN BAHASA INDONESIA}

Pembinaan dan pengembangan bahasa Indonesia tidak dapat dipisahkan. Keduanya memiliki hubungan saling mengisi dan merupakan proses yang berjalan sejajar. Namun, apabila dilihat dari sasarannya, kedua usaha itu sangatlah berbeda. Pembinaan bahasa Indonesia ditujukan pada pemakai bahasa Indonesia, sedangkan pengembangan bahasa Indonesia ditujukan pada bahasa Indonesia itu sendiri. Jadi, pembinaan bahasa Indonesia berurusan dengan bagaimana pemakai bahasa Indonesia harus menggunakan bahasa Indonesia yang baik dan benar dan dapat menggunakannya sesuai dengan kedudukan dan fungsinya; sedangkan pengembangan bahasa Indonesia berurusan dengan bagaimana bahasa Indonesia dapat menjalankan kedudukannya sebagai bahasa nasional dan bahasa ,serta dapat menjalankan fungsinya sebagai bahasa pemersatu, bahasa pemerintahan, bahasa pengantar kependidikan, bahasa perhubungan resmi, dan bahasa pendukung ilmu pengetahuan dan teknologi (Masnur dan Suparno, 1984: 14). Tujuan pembinaan dan pengembangan bahasa Indonesia adalah memelihara dan mengembangkan bahasa Indonesia, bahasa daerah, dan pengajaran bahasa asing, demi meningkatkan mutu, sikap, dan dorongan penggunaan bahasa, agar dapat memenuhi fungsi dan kedudukannya bagi masyarakat pemakai bahasa itu.

Pembinaan dan pengembangan bahasa Indonesia pada masyarakat lebih memungkinkan dilakukan melalui media massa, baik media cetak, maupun media elektronik. Upaya untuk membina penggunaan bahasa Indonesia masyarakat melalui media cetak, seperti surat kabar, lebih efektif dilakukan karena surat kabar merupakan media yang paling murah dan dapat menjangkau seluruh lapisan masyarakat. Masyarakat cenderung lebih terpengaruh terhadap penggunaan bahasa Indonesia di surat kabar dan dengan cepat mengaplikasikannya dalam percakapan sehari-hari atau dalam komunikasi formal. Untuk itulah, diperlukan upaya yang terencana dan sistematis dari pihak surat kabar (redaktur bahasa) untuk secara sadar menghindari penyimpangan-penyimpangan bahasa jurnalistik dari kaidah-kaidah bahasa Indonesia yang telah ditetapkan, agar salah satu tujuan surat kabar yaitu meningkatkan mutu tulisan, serta usaha pemerintah untuk membina dan mengembangkan bahasa Indonesia yang baik dan benar kepada masyarakat dapat terwujud.

Dengan demikian dapat disimpulkan bahwa pembinaan bahasa Indonesia adalah usaha sadar, terencana, dan sistematis tentang peningkatan mutu bahasa Indonesia dengan baik dan benar, sehingga masyarakat pemakai bahasa memiliki kebanggan menggunakannya; sedangkan pengembangan bahasa Indonesia berarti usaha sadar, terencana, dan sistematis tentang peningkatan mutu dan kelengkapan bahasa Indonesia, sehingga dapat digunakan secara efektif sesuai dengan fungsi dan kedudukannya dalam masyarakat Indonesia.

\section{E. PENUTUP}

Penggunaan bahasa Indonesia dalam ragam jurnalistik dalam media massa secara umum belum sesuai dengan kaidah bahasa Indonesia yang baik dan benar. Hal ini karena para redaktur dan editor surat kabar ini belum sepenuhnya berpedoman pada EyD dan KBBI. Penggunaan bahasa yang belum sesuai dengan kaidah bahasa Indonesia yang baik dan benar ini dapat berpengaruh terhadap penggunaan dan pengembangan bahasa Indonesia di masayarakat. Media masa yang beredar di masyarakat memberikan kontribusi yang besar dalam upaya memasyarakatkan bahasa Indonesia yang baik dan benar melalui tulisantulisannya, khususnya pada halaman utama dan terakhir, yang pertama kali dilihat dan dibaca oleh pembaca.

Pihak surat kabar bekerja sama dengan Pusat Bahasa Depdiknas dapat mengadakan penyuluhan, pendidikan, atau pelatihan berbahasa Indonesia yang baik dan benar kepada para wartawan, redaktur, dan editor. 
Para redaktur dan editor bahasa sebaiknya menghindari kesalahan pada semua tataran, baik kesalahan kosakata, pemenggalan, ejaan, morfologi, maupun kesalahan sintaksis.kesalahan semantik, dan kesalahan kewacanaan $\mathrm{Hal}$ ini, tanpa disadari bahwa surat kabar merupakan salah satu media dan menjadi model dalam memasyarakatkan penggunaan bahasa Indonesia yang baik dan benar.

\section{DAFTAR PUSTAKA}

Anwar, Rosihan. 1991. Bahasa Jurnalistik dan Komposisi. Jakarta: Pradnya Paramita.

Budyatna, Muhammad. 2007. Jurnalistik Teori dan Praktik. Bandung Rosdakarya.

Asegaf, Dja'far H. 1991 Jurnalistik Masa Kini: Pengantar ke Praktik Kewartawanan. Jakarta: Ghalia Indonesia.

Badudu, J.S. 1996. Cakrawala Bahasa Indonesia. Jakarta: Gramedia.

Depdiknas. 2001. Pedoman Ejaan Bahasa Indonesia yang Disempurnakan. Jakarta: Balai Pustaka.

Depdiknas. 2001. Pedoman Umum Pembentukan Kata dan Istilah. Jakarta: Balai Pustaka.

Depdiknas. 2005. Kamus Besar Bahasa Indonesia-Edisi Ketiga. Jakarta: Balai Pustaka.

Masnur dan Suparno. 1987. Bahasa IndonesiaKedudukan, Fungsi, Pembinaan dan Pengembangannya. Malang: Jemmars.

Oetama, Jacob. 1987. Perspektif Pers Indonesia. Jakarta: LP3ES.

Rachmat Taufik Hidayat. 2002. "Tentang Bahasa di Media Massa" dalam

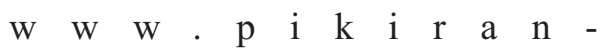
rakyat.com/cetak/10202/12.htm

Reah, Danuta. 2000. The Language of Newspaper. New York: Roudledge.

Suroso 2001. Menuju Pers Demokratis: Kritik atas Profesionalisme Wartawan. Yogyakarta: LSIP. 